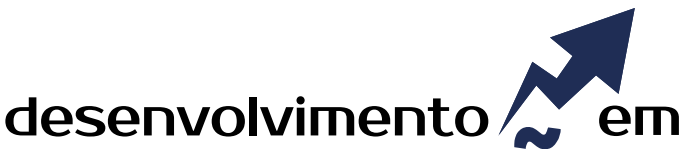 QUESTÃO
}

\section{Aspectos da Heterogeneidade nas Agriculturas Familiares da Microrregião de Toledo/PR e do Território Norte Pioneiro Paranaense}

http://dx.doi.org/10.21527/2237-6453.2019.47.283-300

Recebido em: 19/9/2017

Aceito em: 2/10/2018

\author{
Dimas Soares Junior ${ }^{1}$, Ricardo Ralisch², Nathalie Cialdella ${ }^{3}$, Philippe Pedelahore ${ }^{4}$
}

\begin{abstract}
RESUMO
A heterogeneidade da estrutura produtiva e dos modelos de produção é traço marcante da agricultura brasileira. O conceito de "agricultor familiar" definido em lei, esconde a grande diversidade presente também nesse estrato de produção. A realização do Censo Agropecuário 2006, considerando a estratificação dos diferentes grupos de beneficiários do Pronaf, oferece a possibilidade de identificar e discutir as distinções entre os diferentes tipos de agricultores familiares. Este artigo tem por objetivo aferir, caracterizar e analisar comparativamente a presença de tais distinções no Estado do Paraná e em duas de suas regiões, as quais apresentam históricos distintos de ocupação e índices contrastantes de desenvolvimento. Para tanto, foram analisados dados censitários agrupados considerando informações referentes aos agricultores, unidades produtivas, atividades econômicas, renda e ocupação. Observou-se o predomínio do grupo B do Pronaf no Estado e no Território Norte Pioneiro, e do grupo $\mathrm{C}$ na Microrregião de Toledo. As diferenças mais relevantes entre regiões e entre tipos de agricultores encontram-se em variáveis como o grau de associativismo e a oferta ou não de orientação técnica. Como similaridade, destaca-se a presença marcante de "pronafianos" do grupo B nas classes de idade mais avançada, reforçando a preocupação com os processos de sucessão na agricultura familiar.
\end{abstract}

Palavras-chave: Assistência técnica. Associativismo. Classes de idade. Nível de instrução. Tipologia.

ASPECTS OF HETEROGENEITY IN THE FAMILY AGRICULTURES OF TOLEDO AND NORTH PIONEER REGIONS, PARANÁ STATE, BRAZIL

\begin{abstract}
The heterogeneity of production structure and models is striking in Brazilian agriculture. The concept of "family agriculture" defined in law conceals a great diversity present also in this stratum of production.The 2006 agricultural census with the definition of Pronaf criteria for classification of this public offers the possibility to identify and discuss the distinctions present between the different types of family farmers. This article purpose assess, characterize and analyze comparatively the presence of such distinctions in the Paraná state and in two of its regions, with different occupation histories and contrasting development indexes. For this, the census datas were grouped with information about farmers, farms, economic activities, income and occupation. It was observed that Pronaf correspond to about $75 \%$ of the total farms in Paraná and in the two regions studied, with a predominance of group B in the state and in the Northern Pioneiro and group C in the Toledo region. The most relevant differences observed between regions and between types of farmers are found in variables such as the degree of associativism and the availability or not of agricultural advisory. As a similarity observed, we highlight the remarkable presence of the farmers of the Pronaf group B in the older age classes, reinforcing the concern with the succession processes in family agriculture.
\end{abstract}

Keywords: Age classes. Agricultural advisory. Asssociativism. Instructional level. Typology.

\footnotetext{
${ }^{1}$ Doutor em Agronomia pela Universidade Estadual de Londrina (UEL). Pesquisador do Instituto Agronômico do Paraná (lapar). dimasjr@iapar.br

${ }^{2}$ Doutor em Agronomia pela Universidade Estadual Paulista Júlio de Mesquita Filho (Unesp). Professor da Universidade Estadual de Londrina (UEL).ralisch@uel.br

${ }^{3}$ Doutora em Systèmes Agraires et Développement pela AgroParisTech, França. Pesquisadora do Centre de Coopération Internationale en Recherche Agronomique pour le Développement (Cirad).nathalie.cialdella@cirad.fr

${ }^{4}$ Doutor em Géographie, Aménagement, pela Universidade de Toulouse 2. França. Pesquisador do Centre de Coopération Internationale en Recherche Agronomique pour le Développement (Cirad), França.philippe.pedelahore@cirad.fr
} 
A heterogeneidade da base produtiva e do perfil econômico e social dos produtores é uma das características mais marcantes da agricultura brasileira, característica presente também em seu estrato familiar (SCHENEIDER; CASSOL, 2017; SANTOS; VIEIRA FILHO, 2012; GUANZIROLI; BUAINAIN; DI SABBATO, 2012; GRAZIANO DA SILVA, 2010). TaI condição tem feito com que, como ressaltam Kageyama, Bergamasco e Oliveira (2013), a cada novo recenseamento agropecuário, em razão dos aprimoramentos na coleta dos dados, sigam-se propostas de tipologias de produtores e de discussão dos resultados divulgados, considerando as distinções observadas junto aos diferentes tipos de agricultores.

Exemplos dessa afirmação são encontrados para o Estado do Paraná. Com base nos dados do Censo Agropecuário de 1980, Chang e Sereia (1993) classificaram os estabelecimentos rurais em cinco diferentes categorias sociais às quais agregaram as atividades produtivas predominantes para apresentar uma tipologia no âmbito das mesorregiões homogêneas paranaenses, conforme a definição do Instituto Brasilieiro de Geografia e Estatística (IBGE). Já Doretto, Laurenti e Del Grossi (2001) apresentaram, com base nos dados do Censo Agropecuário de 1995/96, uma tipologia na esfera dos municípios do Estado, classificando os estabelecimentos rurais em duas categorias não familiares e familiares -, e subdividindo os dois diferentes tipos em virtude de suas atividades produtivas predominantes.

No plano nacional, iniciativa no sentido de oferecer uma tipologia de agricultores foi empreendida pelo IBGE que, ao considerar a consolidação do Programa Nacional para o Fortalecimento da Agricultura Familiar (Pronaf), o qual fora instituído em 1996, e a aprovação da "Lei da Agricultura Familiar"5 (Lei n 11.326 de 24/07/2006), atendeu a demanda do então Ministério do Desenvolvimento Agrário (MDA) ${ }^{6}$ e adotou o conceito no recenseamento de 2006, disponibilizando variáveis segundo a classificação legal (IBGE, 2014).

Posteriormente, o IBGE disponibilizaria também tabulações especiais que levam em conta as mudanças normativas ocorridas no Pronaf com a estratificação do público potencial do crédito rural em cinco diferentes grupos, tomando como critérios a presença ou não de empregados temporários, de empregados permanentes e a faixa de renda bruta (IBGE, 2014), tornando possível, assim, a realização de estudos que buscam identificar e interpretar aspectos associados à diversidade existente nesse segmento de agricultores (AQUINO et al., 2014).

É nesse propósito que se inscreve o presente artigo, o qual tem por objetivos aferir, caracterizar e analisar comparativamente as principais distinções entre os tipos de agricultores familiares, a partir da definição dos grupos de beneficiários do Pronaf no Estado do Paraná e em duas de suas regiões, selecionadas por apresentarem carac-

\footnotetext{
${ }^{5}$ A referida lei estabelece critérios para a classificação dos estabelecimentos familiares e para a formulação de políticas públicas direcionadas à agricultura familiar e aos empreendimentos familiares rurais (BRASIL, 2006). Define como agricultor familiar e empreendedor familiar rural aquele que atenda simultaneamente aos requisitos de a) não possuir, a qualquer título, área maior do que quatro módulos fiscais; b) utilizar predominantemente a mão de obra da família; c) ter percentual mínimo da renda familiar originada de atividades econômicas de seu estabelecimento ou empreendimento; e d) ser o responsável pela direção do estabelecimento.

${ }^{6}$ Atual Secretaria Especial de Agricultura Familiar e do Desenvolvimento Agrário (Sead), vinculada à Casa Civil da Presidência da República.
} 
terísticas distintas em seus processos históricos de ocupação e, no presente, por graus contrastantes de desenvolvimento humano, econômico e rural, quais sejam a Microrregião de Toledo e o Território Norte Pioneiro, destacando variáveis associadas ao perfil do agricultor e da unidade produtiva, às atividades econômicas, à ocupação e à renda nos estabelecimentos rurais familiares.

\section{MATERIAL E MÉTODOS}

A Figura 1 apresenta a localização das regiões estudadas. Descrições detalhadas da Microrregião de Toledo e do Território Norte Pioneiro, seus históricos de ocupação e suas características atuais, podem ser encontrados respectivamente em Rippel (2005) e Ipardes (2007).

Os dados foram obtidos no Sistema IBGE de Recuperação Automática (Sidra), tendo sido gerados por meio das tabulações especiais do Censo Agropecuário de 2006 realizadas pelo IBGE no âmbito de trabalho conjunto com o MDA.Tais tabulações adotaram o método de exclusões sucessivas e complementares de modo a classificar os estabelecimentos rurais recenseados considerando o disposto na Lei $n^{\circ} 11.326$ e na estratificação do público-alvo do Pronaf, caracterizando cinco diferentes grupos de agricultores familiares.

O grupo " $\mathrm{A}$ " identifica exclusivamente os estabelecimentos constituídos a partir de ações de política fundiária. Nos grupos "B" e "C", a contratação de empregados temporários é limitada a 180 dias/ano, não podendo ocorrer contratação de empregado permanente. A renda bruta anual7 deve ser menor ou igual a $\mathrm{R} \$ 3.000$ no grupo " $\mathrm{B}$ ", $\mathrm{e}$ encontrar-se entre $\mathrm{R} \$ 3.000$ e R\$ 16.000 no grupo "C" (IBGE, 2014).

Já nos grupos " $D$ " e " $E$ ", admite-se a contratação de até três empregados temporários por 180 dias ou mais ao ano, limitando-se a três o número de empregados permanentes contratados. Para o grupo " $\mathrm{D}$ ", a renda bruta anual deve estar entre $\mathrm{R} \$$ 16.000 e $R \$ 45.000$, ficando no grupo "E" entre $R \$ 45.000$ e $R \$ 80.000 . .^{8}$ Os agricultores familiares identificados como "não pronafianos" atendem às diretrizes da Lei no 11.326, mas seja em decorrência da contratação de mão de obra, seja por extrapolar os limites de renda previstos, não se enquadram em nenhum dos grupos descritos.

Considerando os objetivos propostos, foram selecionadas nove variáveis entre aquelas disponíveis no recenseamento, quais sejam: os grupos de área total, as classes de idade, o nível de instrução da pessoa responsável pela direção da unidade produtiva, o local de moradia, a associação à cooperativa e/ou à entidade de classe, o recebimento de orientação técnica, a origem da orientação técnica recebida, os grupos de atividade econômica, e, ainda, a ocorrência de atividade econômica fora do estabelecimento por parte do responsável pela direção ou algum outro membro da família.

\footnotetext{
7 Dos valores apurados de renda bruta anual no período censitário, deduzem-se, para efeito de enquadramento, os "rebates", que são reduções autorizadas de até 30\%,60\%, $70 \%$ e $80 \%$ respectivamente nos grupos de B a E, os quais são estipulados em virtude do tipo de atividades produtivas desenvolvidas.

${ }^{8}$ Os valores indicados ( $R \$ 3.000, R \$ 16.000, R \$ 45.000$ e $R \$ 80.000$ ) referem-se a dezembro/2006. Corrigidos pelo Índice Geral de Preços - disponibilidade interna (IGP-DI) da Fundação Getúlio Vargas, corresponderiam a respectivamente: $\mathrm{R} \$ 5.663, \mathrm{R} \$ 30.204, \mathrm{R} \$ 84.949$ e $\mathrm{R} \$ 151.021 \mathrm{em}$ abril/2017.
} 


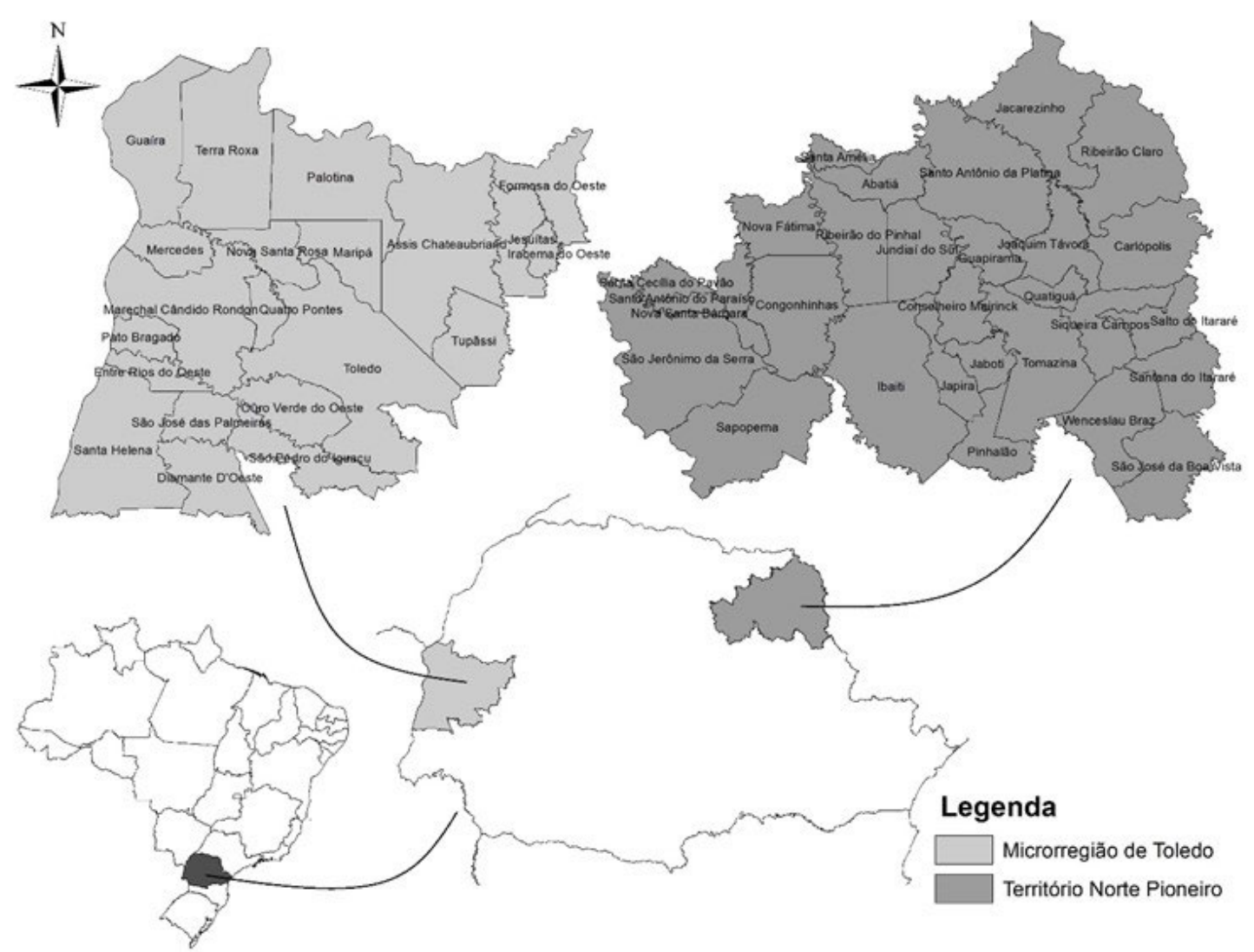

Fonte: Área de Socioeconomia - Instituto Agronômico do Paraná.

Após coletadas as tabelas selecionadas no Sidra em âmbito do Estado e dos municípios, os dados foram agregados em planilhas eletrônicas conforme a composição das duas regiões de estudo e tabulados segundo parâmetros da estatística descritiva.

\section{RESULTADOS E DISCUSSÃO}

Analisando-se primeiramente os aspectos associados aos agricultores e suas unidades produtivas, constata-se que a participação dos estabelecimentos familiares no número total de estabelecimentos rurais era levemente mais expressiva na Microrregião de Toledo, onde as 24.486 unidades familiares correspondiam a $84,2 \%$ do total, quando comparada ao Território Norte Pioneiro (21.469 estabelecimentos, 79,4\% do total) ou ao Estado do Paraná (371.063 estabelecimentos, 81,6\% do total).

Tal condição justifica-se como legado dos processos históricos de ocupação do Estado e das duas diferentes regiões, diferenciando-se o Oeste Paranaense, região na qual se insere a Microrregião de Toledo, por ter recebido, a partir de 1946, empreendimentos conduzidos por companhias colonizadoras que privilegiaram como estrutura fundiária a presença da pequena unidade de produção familiar, ajustando-se, assim, ao seu público-alvo, qual seja, colonos gaúchos e catarinenses com capacidade limitada de investimento (RIPPEL, 2005). 
Essa situação mantém-se quando considerados somente os estabelecimentos familiares beneficiários do Pronaf, ${ }^{9}$ os quais correspondiam a 76,7\%, 75,2\% e 73,5\% do total de estabelecimentos respectivamente na Microrregião de Toledo, Território Norte Pioneiro e Paraná.Ao analisar, contudo, a participação relativa de cada um dos cinco grupos de agricultores familiares "pronafianos", as distinções internas e externas às regiões estudadas evidenciam-se (Figura 2).

O "pronafiano B" era o grupo predominante no Território Norte Pioneiro e no Estado do Paraná, condição observada também no Brasil (AQUINO et al., 2014), à medida que o "pronafiano C" predominava na Microrregião de Toledo, seguido pelo grupo D. Já os "pronafianos E", os quais no Paraná representavam somente $4 \%$ dos estabelecimentos familiares e no Território Norte Pioneiro limitavam-se a $2 \%$ dos mesmos, na Microrregião de Toledo alcançavam $10 \%$ de participação.

Figura 2 - Participação relativa do número de estabelecimentos rurais familiares considerando os critérios de enquadramento do Pronaf Paraná

- Microrregião de Toledo e Território Norte Pioneiro, 2006

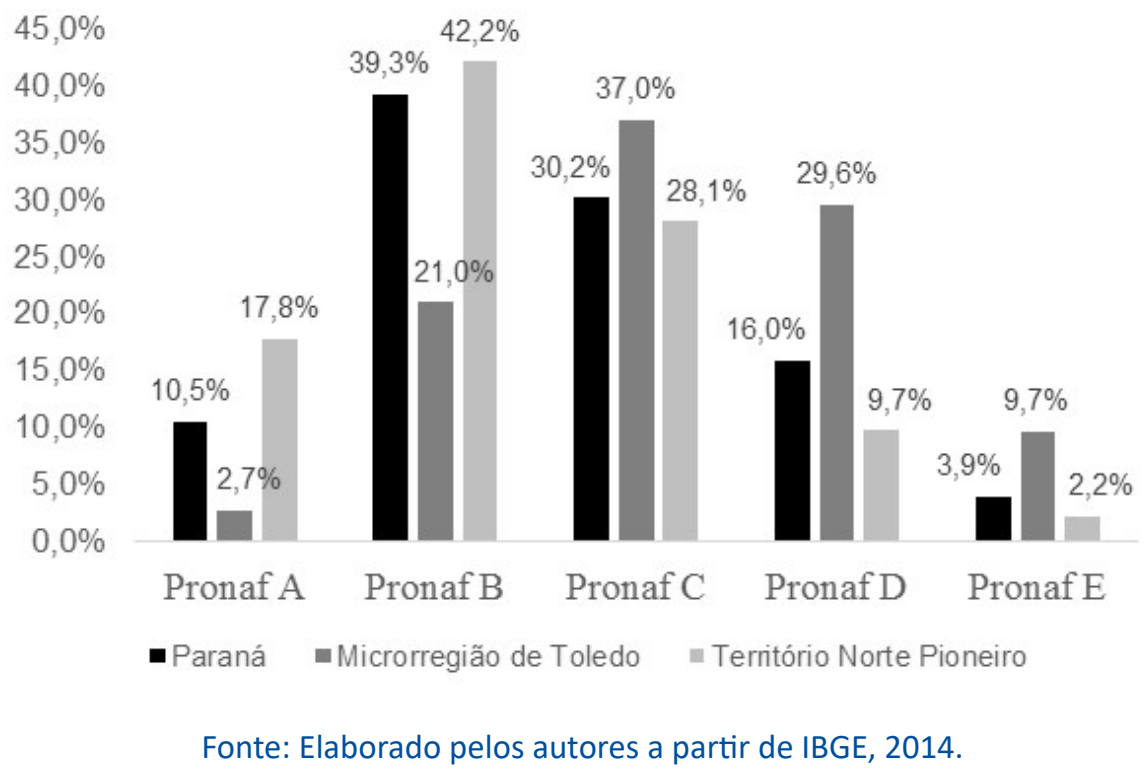

Os agricultores do Pronaf A apareciam com destaque no Território Norte Pioneiro, alcançando cerca de $18 \%$ do total, mas não representavam sequer $3 \%$ dos agricultores da microrregião de Toledo e pouco mais de $10 \%$ dos agricultores do Estado, refletindo, assim, a maior importância relativa das políticas de acesso a terra para aquele Território, seja em modalidades clássicas, como os assentamentos rurais (INCRA, 2014), seja em modalidades alternativas do crédito fundiário, via empreendimentos, como os chamados "Banco da Terra" (SANTOS, 2005) e as "Vilas Rurais". ${ }^{10} \mathrm{~A}$ análise dos grupos de

\footnotetext{
${ }_{9}^{9}$ Doravante designados aqui como "pronafianos".

${ }^{10}$ Atividade integrante do subcomponente "Alívio da Pobreza no Meio Rural" do Projeto "Paraná 12 Meses" firmado entre o Banco Mundial e o governo do Estado do Paraná, as "Vilas Rurais" possuíam como objetivo geral a "... meIhoria das condições de vida de trabalhadores rurais volantes, mantendo-os no meio rural" (IPARDES, 2006, p. 2), sendo, para isso, realizadas em locais próximos aos centros urbanos do Estado, inclusive distritos e povoados. Contando com lotes de $5.000 \mathrm{~m}^{2}$ e moradias de $44 \mathrm{~m}^{2}$, as Vilas possuíam, além da função básica de alimentação, a perspectiva de receberem outras atividades, não sendo o lote, contudo, o único meio de geração de renda da família. A ideia básica subjacente era a de que os moradores poderiam trabalhar em fazendas vizinhas, mas desenvolveriam culturas de subsistência em seus lotes, comercializando o excedente (SOUZA; DEL GROSSI, 2000).
} 
área total entre os estabelecimentos familiares "pronafianos" (Tabela 1) indica que, ao menos, 91\% dos estabelecimentos dos grupos A, B, C e D possuíam menos de 50 ha, número expressivo considerando que nas regiões estudadas o limite de área para as unidades familiares, conforme a normativa legal de quatro módulos fiscais, é de 72 ha, sendo, em média, de 75 ha para Estado do Paraná (IBGE, 2014). Entre os "pronafianos $B$ " predominavam estabelecimentos entre 2 ha e 5 ha, enquanto entre os "pronafianos D" eram os estabelecimentos entre 20 ha e 50 ha que prevaleciam independentemente da região.

Tabela 1 - Participação relativa no número de estabelecimentos rurais ${ }^{11}$ familiares

"Pronafianos", considerando os grupos de estabelecimentos e os grupos de área total. Paraná - Microrregião de Toledo e Território Norte Pioneiro, 2006 (em \%)

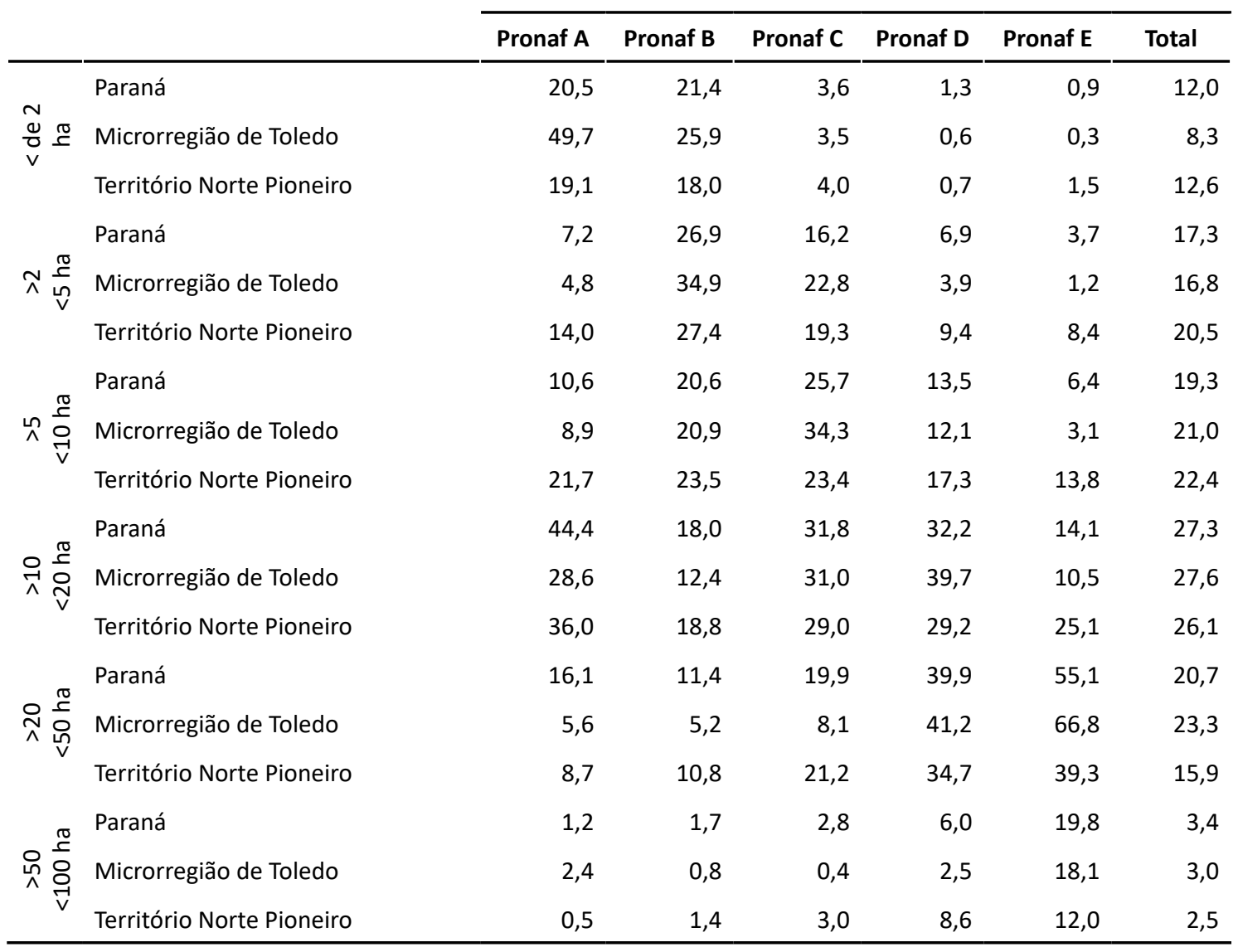

Fonte: Elaborado pelos autores a partir de IBGE, 2014.

Entre os "pronafianos" de maior renda - grupo E - da microrregião de Toledo, 85\% possuem mais de 20 ha, número que se reduz para $51 \%$ quando considerado o mesmo grupo no Território Norte Pioneiro, condição possivelmente justificada pela importância que ali possui a cafeicultura, atividade mais intensiva em geração de renda por unidade de área e historicamente associada aos processos de ocupação do Território (IPARDES, 2007).

\footnotetext{
${ }^{11}$ Somente os estabelecimentos explorados pelo proprietário.
} 
Outro aspecto a ressaltar é o fato de que praticamente a metade dos estabelecimentos do Pronaf A na Microrregião de Toledo possui menos de 2 ha, e $90 \%$ desses estão entre 0,5 ha e 1,0 ha, indicando que nessa região a política pública principal, responsável pelo surgimento de estabelecimentos rurais desse grupo, foi provavelmente a instalação de "Vilas Rurais" e não o crédito fundiário e a reforma agrária prevalecentes no Território Norte Pioneiro, as quais resultaram em $45 \%$ das unidades produtivas desse grupo entre os de área total acima de 10 ha naquela região.

Com efeito, na Microrregião de Toledo as 21 "Vilas Rurais"12 instaladas somaram 615 famílias beneficiárias entre 1995 e 2003, enquanto os projetos de assentamento do Instituto Nacional de Colonização e Reforma Agrária (Incra) atenderam somente 150 famílias em dois assentamentos realizados entre 1981 e 2013, com lotes de área total média de 24,7 ha (INCRA, 2014), sendo beneficiadas naquela microrregião somente cerca de 15 famílias em empreendimento do tipo "Banco da Terra" (SANTOS, 2005).

Por outro lado, no Território Norte Pioneiro, segundo as mesmas fontes, foram instituídas 32 "Vilas Rurais", as quais beneficiaram 1.250 famílias, 29 projetos de assentamento com 1.313 famílias assentadas e 20,6 ha de área total média, sendo instaladas 469 famílias em empreendimentos do "Banco da Terra". Tais números podem ser explicados não somente pelo processo de colonização das regiões estudadas, mais recente e estruturado na Microrregião de Toledo, como também pelo menor dinamismo no desenvolvimento da agropecuária no Território Norte Pioneiro.

A análise das classes de idade (Tabela 2) indica que, quer seja no estado ou nas regiões de estudo, os agricultores das faixas entre 35 e 45 e 45 e 55 anos, surgem com maior representatividade não somente junto aos "pronafianos $A^{\prime}$, unidades produtivas mais recentemente instaladas as quais congregam também as maiores proporções de agricultores mais jovens ( 25 a 35 anos), mas também junto aos "pronafianos E", decrescendo sua participação à medida que diminui a renda entre os grupos $D$ e $B$.

No grupo B os responsáveis pelo estabelecimento com mais de 55 anos de idade são os mais representativos, alcançando $49 \%$ do total no Paraná e no Território Norte Pioneiro e 53\% na Microrregião de Toledo. A associação entre faixa etária elevada, fim da atividade profissional, menores renda bruta e capacidade de investimento, compõem o quadro de dificuldades para a sucessão geracional de unidades produtivas familiares já relatado por Sacco dos Anjos, Caldas e Pollnow (2014), o qual é mais fortemente observado junto aos estabelecimentos desse grupo.

Tal condição, como lembram aqueles autores, tem sido marcante nos Estados do Sul do país, sendo agravada pelo fato de que, ao aumento na expectativa de vida e à redução da taxa de fecundidade, os quais justificam o envelhecimento da população brasileira de forma geral, soma-se, nas zonas rurais, a permanência do êxodo populacional claramente jovem e feminino, culminando no processo de masculinização da população rural, também identificado no Território como um todo (SOARES JÚNIOR et al., 2017).

${ }^{12}$ Dickow, B, comunicação pessoal, 17/11/2014; Cohapar - Companhia de Habitação do Paraná, Brasil. 
Tabela 2 - Participação relativa no número de estabelecimentos rurais familiares "Pronafianos", considerando os grupos de estabelecimentos, as classes de idade e o nível de instrução da pessoa responsável pela direção.

Paraná - Microrregião de Toledo e Território Norte Pioneiro, 2006 (em \%)

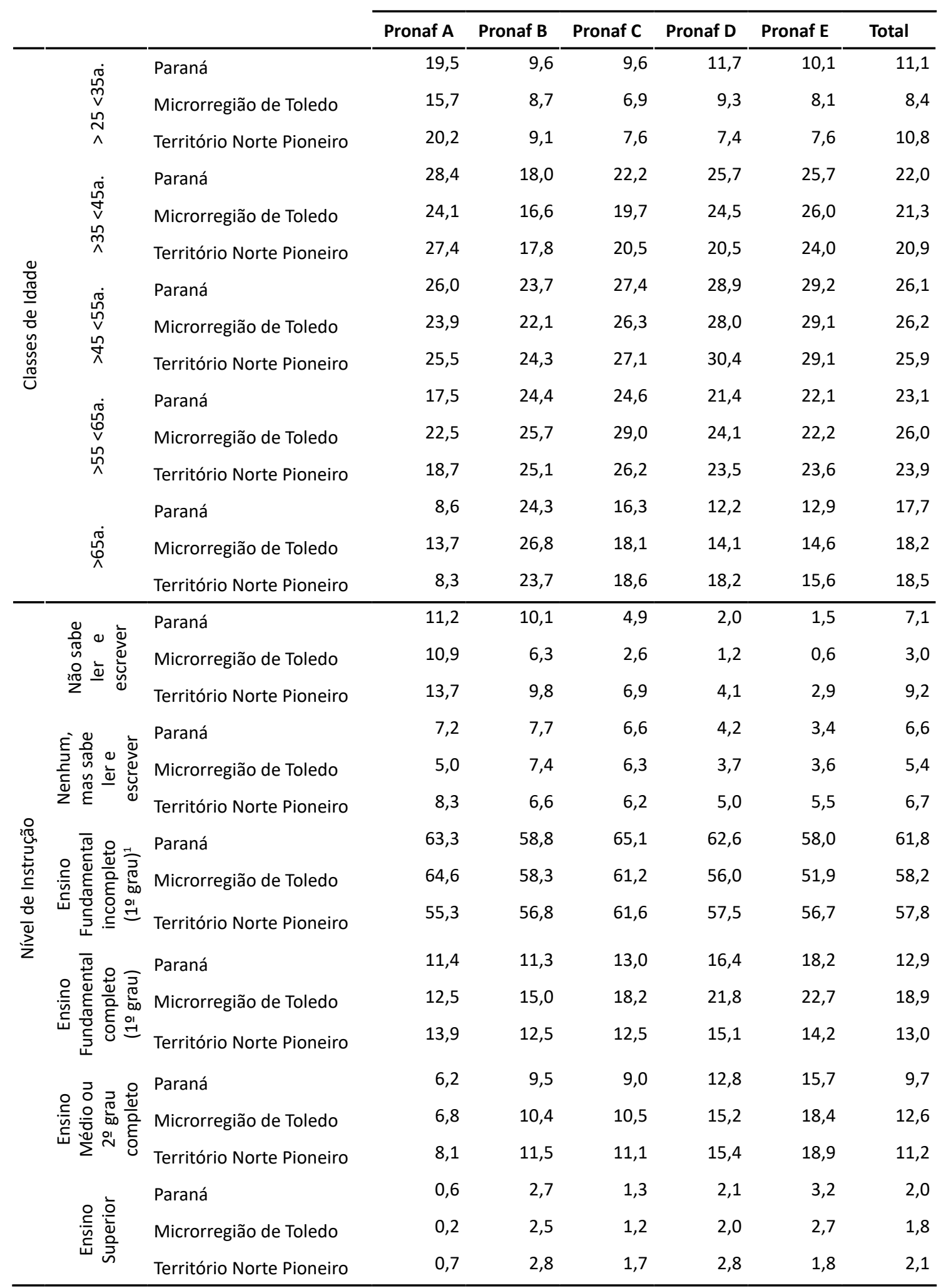

Fonte: Elaborado pelos autores a partir de IBGE, 2014. 
Ainda na Tabela 2, analisando o nível de instrução da pessoa que dirige o estabelecimento, é possível constatar que, embora o Ensino Fundamental incompleto seja predominante entre os diferentes grupos de agricultores no Estado e nas regiões estudadas, correspondendo ao mínimo de 52\% das unidades recenseadas, existem importantes distinções que merecem ser discutidas.

Observa-se que as taxas de ocorrência de agricultores que não sabem ler ou escrever ou que escrevem e leem sem que disponham de educação formal, ainda são preocupantes. Alcançam $22 \%$ dos estabelecimentos do grupo A no Território Norte Pioneiro, proporção que cai com o aumento da renda entre os grupos B e E, alcançando, entre esses últimos, $8 \%$ do total. O mesmo comportamento é observado, em menores proporções, na Microrregião de Toledo, onde tal condição alcança $16 \%$ no grupo A, mas somente $4 \%$ junto ao grupo $\mathrm{E}$.

Os "pronafianos E" são aqueles que concentram a maior proporção de agricultores com melhor nível de instrução formal, posto que entre $19 \%$ e $21 \%$ desses no Estado e nas regiões de estudo completaram o Ensino Médio ou o Ensino Superior, corroborando os estudos que indicam a correlação entre o nível de educação formal e a capacidade de desenvolvimento econômico da atividade agrícola, uma vez que, como destacam Souza Filho et al. (2011), a informação desempenha importante papel no processo de distinção entre as oportunidades e a capacidade de explorá-las efetivamente, condição associada não somente ao acesso a determinados tipos de informações, mas também ao grau de escolarização e de formação profissional do agricultor.

Vê-se, na Tabela 3, que o estabelecimento rural como local de moradia surge em maiores proporções junto aos "pronafianos A", entre os quais alcança mais de $93 \%$ no Estado e na Microrregião de Toledo. A análise desse dado, ao lembrarmos que nessa Microrregião 49,7\% dos estabelecimentos do grupo A possuem menos de 2 ha de área total, nos leva a crer que essa situação decorre da diversificação das ocupações e das rendas nas áreas rurais, com perda da exclusividade das rendas agrícolas entre a população rural, sendo o avanço da pluriatividade na economia familiar marcado pela mobilidade das pessoas que residem no campo e trabalham no meio urbano, condição facultada pela melhoria nas condições de deslocamento e transporte, condição observada em estudo realizado na região (LAURENTI; DORETTO; DEL GROSSI, 2003).

O absenteísmo cresce na mesma direção do crescimento da renda entre os grupos $\mathrm{B}$ a $\mathrm{E}$ sendo sempre superior a $21 \%$, alcançando os maiores valores entre os agricultores do grupo E na Microrregião de Toledo, onde cerca de 38\% dos agricultores responsáveis pelo estabelecimento residem fora dos mesmos, sendo $24 \%$ desses em zonas urbanas, mesma proporção observada no Estado.

Tais resultados mostram que, para uma parcela da população rural economicamente ativa, o estabelecimento agropecuário deixa de ser o lugar de moradia e assume o caráter estrito de unidade produtiva. 
Tabela 3 - Participação relativa no número de estabelecimentos rurais familiares "Pronafianos", considerando os grupos de estabelecimentos, o local de moradia e a associação à cooperativa e/ou à entidade de classe $^{13}$. Paraná - Microrregião de Toledo e Território Norte Pioneiro, 2006 (em \%)

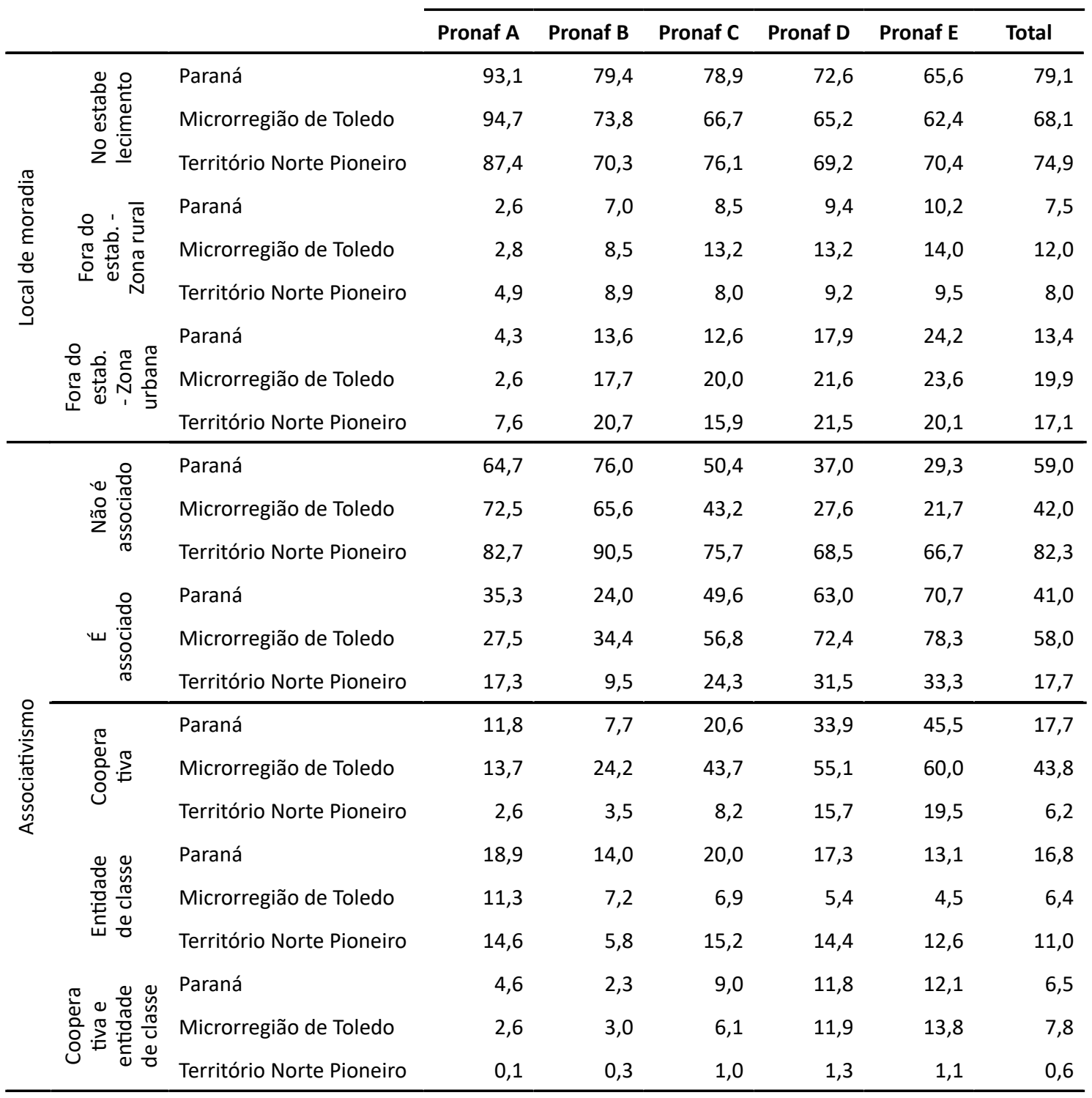

Fonte: Elaborado pelos autores a partir de IBGE, 2014.

As distinções mais marcantes entre os grupos e regiões estudadas manifestam-se nas variáveis elencadas a seguir. Ainda na Tabela 3 é possível constatar que o grau de associativismo na Microrregião de Toledo, o qual inicia-se com 28\% dos "pronafianos A", amplia-se na mesma direção do crescimento da renda entre os grupos $B$ a $E$, chegando a $78 \%$ entre os agricultores do grupo $\mathrm{E}$, sustentado sobretudo pela associação às cooperativas, que cresce na mesma direção, alcançando $16 \%$ no grupo A e $74 \%$ junto aos "pronafianos E" daquela microrregião. ${ }^{14} \mathrm{Em}$ direção oposta, a associação a entidades de classe diminui de $11 \%$ para somente $4 \%$ entre os grupos $A$ e $E$.

\footnotetext{
${ }^{13}$ Sindicatos, associações/movimentos de produtores e moradores, etc.

${ }^{14}$ Considerando os agricultores que são associados às cooperativas e também às entidades de classe.
} 
De outra maneira, no Território Norte Pioneiro a manifestação do associativismo entre os diferentes grupos de agricultores é distinta, uma vez que os agricultores do grupo A apresentam índice superior aos do grupo B, justificado possivelmente pela associação aos movimentos de luta pela terra, mas limitado a $17 \%$ do total. 0 associativismo está presente entre um terço dos agricultores do grupo $\mathrm{E}$ naquele Território, e o cooperativismo é incipiente, não superando $20 \%$ nesse mesmo grupo, limitando-se a menos de $4 \%$ nos grupos A e B.

Considerando a importância de organizações cooperativas no histórico de ocupação da Microrregião de Toledo (MADUREIRA, 2012), é plausível aceitar que a diferença observada no grau de cooperativismo entre as duas regiões de estudo tem reflexos nos índices de desenvolvimento econômico e sociais díspares atualmente observados, pois, como descrito por aquele autor, as agroindústrias cooperativas presentes na Microrregião de Toledo desempenham papel determinante no encadeamento e agregação de valor entre as cinco principais cadeias produtivas regionais, quais sejam a da soja, do milho, das proteinas animais (suínos e aves) e a do leite, tendo as quatro primeiras importante inserção nos mercados nacionais e internacionais.

Outra distinção ainda mais acentuada entre os grupos de agricultores e as regiões estudadas diz respeito à disponibilidade de assistência técnica e à origem desta quando recebida (Tabela 4), aspectos que devem ser tomados como relevantes para os processos de inovação, independentemente dos sistemas de produção adotados.

Observa-se que entre os agricultores do grupo A a carência de assistência técnica é indistinta, considerando as regiões de estudo, nas quais $66 \%$ dos estabelecimentos não recebeu orientação, e o Estado, onde tal índice chega a 69\%.

Quando, entretanto, a análise é realizada junto aos demais grupos, o cenário se altera. Na Microrregião de Toledo, a ausência de orientação técnica continua alta (65\%) entre os "pronafianos B", mas é reduzida fortemente a partir do grupo C, grupo junto ao qual a orientação alcança $73 \%$ dos estabelecimentos, sendo $38 \%$ desses regularmente.

Junto aos grupos $D$ e $E$ a presença de técnicos é ainda mais evidenciada, chegando de forma regular ou ocasional a pelo menos $91 \%$ das unidades produtivas. Já no Território Norte Pioneiro a ausência de técnicos era ainda maior junto aos grupos $B$ e $C$, quando comparados aos "pronafianos $A$ " e reduzia-se nos grupos $D$ e $E$, sem alcançar, contudo, sequer a metade dos estabelecimentos.

Tais números justificam-se pela presença das cooperativas que se constituem na principal origem de assistência técnica para os agricultores dos grupos $B$ a $E$ na Microrregião de Toledo, seguidas das empresas integradoras, a segunda origem em importância para os "pronafianos C, D e E".Por sua via, a orientação técnica oferecida no Território Norte Pioneiro é principalmente pública junto aos agricultores do grupo $A$, no qual alcança $91 \%$ entre aqueles que recebem assistência, e também nos grupos B, C e D.

Ressalte-se que os aspectos quantitativos não devem inibir a discussão acerca da natureza da orientação técnica oferecida, a qual, no caso das cooperativas e empresas integradoras, mais se aproxima, como discutem Silva (2014) e Grigolo et al. (2011), de relações comerciais de compra e venda de insumos, transferência de "pacotes tecnológicos" e manutenção de padrões de produção preestabelecidos, limitando a autonomia do agricultor nos processos decisórios. 
Tabela 4 - Participação relativa no número de estabelecimentos rurais familiares

"Pronafianos", considerando os grupos de estabelecimentos, o recebimento de orientação técnica e a origem da orientação técnica recebida. ${ }^{15}$

Paraná - Microrregião de Toledo e Território Norte Pioneiro, 2006 (em \%)

\begin{tabular}{|c|c|c|c|c|c|c|c|c|}
\hline & & \\
\hline & & & Pronaf A & Pronaf B & Pronaf C & Pronaf D & Pronaf E & Total \\
\hline \multirow{9}{*}{ 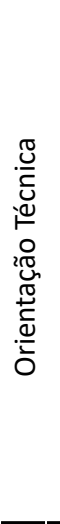 } & \multirow{3}{*}{ 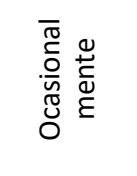 } & Paraná & 17,6 & 10,5 & 25,2 & 30,4 & 28,0 & 19,6 \\
\hline & & Microrregião de Toledo & 19,4 & 18,5 & 34,8 & 36,9 & 31,5 & 31,3 \\
\hline & & Território Norte Pioneiro & 21,2 & 9,4 & 18,0 & 22,6 & 22,7 & 15,5 \\
\hline & \multirow{3}{*}{ 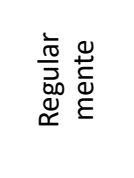 } & Paraná & 12,9 & 6,9 & 24,8 & 46,7 & 54,5 & 21,2 \\
\hline & & Microrregião de Toledo & 14,5 & 16,7 & 37,9 & 54,1 & 63,3 & 40,1 \\
\hline & & Território Norte Pioneiro & 12,3 & 4,6 & 11,9 & 18,6 & 25,9 & 9,9 \\
\hline & \multirow{3}{*}{ 일 } & Paraná & 69,5 & 82,6 & 49,9 & 22,9 & 17,5 & 59,3 \\
\hline & & Microrregião de Toledo & 66,1 & 64,9 & 27,2 & 9,0 & 5,2 & 28,7 \\
\hline & & Território Norte Pioneiro & 66,5 & 85,9 & 70,1 & 58,8 & 51,4 & 74,6 \\
\hline \multirow{21}{*}{ ס } & \multirow{3}{*}{$\frac{.0}{\frac{0}{3}}$} & Paraná & 49,7 & 38,4 & 25,0 & 13,8 & 11,3 & 24,7 \\
\hline & & Microrregião de Toledo & 37,4 & 17,9 & 10,9 & 6,5 & 5,5 & 9,6 \\
\hline & & Território Norte Pioneiro & 91,4 & 54,9 & 50,7 & 40,4 & 34,9 & 58,9 \\
\hline & \multirow{3}{*}{ 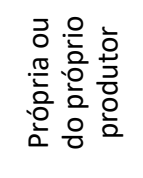 } & Paraná & 7,6 & 18,8 & 9,4 & 8,7 & 10,3 & 10,7 \\
\hline & & Microrregião de Toledo & 8,8 & 9,4 & 6,8 & 7,1 & 8,0 & 7,4 \\
\hline & & Território Norte Pioneiro & 7,8 & 22,6 & 14,9 & 19,4 & 20,1 & 16,0 \\
\hline & \multirow{3}{*}{ 号 } & Paraná & 28,9 & 24,7 & 37,6 & 46,5 & 58,4 & 39,1 \\
\hline & & Microrregião de Toledo & 28,1 & 52,1 & 62,5 & 68,6 & 72,0 & 64,5 \\
\hline & & Território Norte Pioneiro & 2,2 & 12,5 & 24,2 & 35,3 & 36,1 & 18,6 \\
\hline & \multirow{3}{*}{ 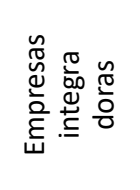 } & Paraná & 11,1 & 11,9 & 22,7 & 30,1 & 21,1 & 22,1 \\
\hline & & Microrregião de Toledo & 17,5 & 12,4 & 13,7 & 15,6 & 15,7 & 14,6 \\
\hline & & Território Norte Pioneiro & 1,1 & 6,3 & 9,3 & 9,6 & 11,2 & 6,8 \\
\hline & \multirow{3}{*}{ 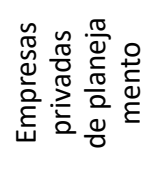 } & Paraná & 8,1 & 8,8 & 12,4 & 12,5 & 14,4 & 11,6 \\
\hline & & Microrregião de Toledo & 6,4 & 10,6 & 12,7 & 15,3 & 17,0 & 13,9 \\
\hline & & Território Norte Pioneiro & 0,9 & 4,4 & 5,1 & 4,6 & 10,1 & 4,1 \\
\hline & \multirow{3}{*}{$\sum_{0}^{0}$} & Paraná & 1,5 & 0,9 & 0,3 & 0,2 & 0,1 & 0,5 \\
\hline & & Microrregião de Toledo & 15,2 & 1,1 & 0,6 & 0,5 & 0,3 & 0,8 \\
\hline & & Território Norte Pioneiro & 0,1 & 1,0 & 0,4 & 0,2 & 0,6 & 0,4 \\
\hline & \multirow{3}{*}{$\begin{array}{l}\stackrel{n}{\overparen{5}} \\
\stackrel{5}{5}\end{array}$} & Paraná & 1,4 & 2,1 & 2,1 & 2,4 & 2,1 & 2,1 \\
\hline & & Microrregião de Toledo & 2,3 & 3,4 & 2,6 & 2,2 & 1,8 & 2,4 \\
\hline & & Território Norte Pioneiro & 0,2 & 2,2 & 2,0 & 3,2 & 0,6 & 1,8 \\
\hline
\end{tabular}

Fonte: Elaborado pelos autores a partir de IBGE, 2014.

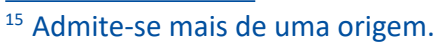


Adicionalmente, a fragilização da Assistência Técnica e Extensão Rural (Ater) pública implica também limitação do alcance dos programas de governo voltados ao meio rural, uma vez que esse tem sido um dos principais papéis desempenhados por tais organismos de Ater nos Estados do sul do país (Grigolo et al., 2011)

Analisando agora aspectos associados às atividades econômicas, renda e ocupação nas unidades produtivas nas regiões de estudo, observa-se a heterogeneidade existente também no que diz respeito à composição das receitas obtidas, levando-se em conta os grupos e classes de atividades econômicas ${ }^{16}$ (Tabela 5).

Considerando-se o número de estabelecimentos, constata-se que, na Microrregião de Toledo, a pecuária e a criação de outros animais é o grupo de atividade mais importante entre os "pronafianos A e B", enquanto a produção de lavouras temporárias surge como primeira atividade junto aos grupos $C, D$ e $E$, sendo esses dois últimos os mais especializados, com cerca de $70 \%$ dos estabelecimentos com predomínio de receitas nas lavouras temporárias.

No detalhamento das classes desse grupo econômico constata-se que o cultivo da soja é a atividade mais importante na geração de receitas nos estabelecimentos "pronafianos C", participação que aumenta nos grupos D e E respectivamente. Se, por um lado, no grupo E tal participação se encontra próxima daquela observada no Estado, no grupo C é superior ao dobro do índice verificado no Paraná.Com efeito, como constatam Soares Júnior et al. (2017), o Estado do Paraná e as regiões estudadas vivenciaram, a partir dos anos 2000, um processo de avanço no cultivo daquela oleaginosa perante a grande demanda proteica no âmbito mundial, fenômeno similar ao ocorrido na Argentina, qual seja marcado pela expansão na área cultivada e pelos ganhos tecnológicos, caracterizado por aqueles autores como sojificação à paranaense, em alusão à sojificação da agricultura argentina descrita por Barbosa e Nogueira Júnior (2007).

Ao analisar-se o grupo "pecuária e criação de outros animais", verifica-se que a criação de bovinos, a qual, muito embora não especificado, diz respeito sobretudo à produção de leite, é a atividade mais importante na geração de receitas em cerca de um terço ou mais dos "pronafianos A, B e C" na Microrregião de Toledo, perdendo importância junto aos grupos $D$ e E, condição observada também no Estado do Paraná e no Território Norte Pioneiro.

A importância da pecuária leiteira na região e a contribuição do estrato de produção familiar, foi constatada também por Silva, Camara e Telles (2016), que, estudando a distribuição espacial da produção de leite no Estado do Paraná, identificaram um grande cluster de produção em sua região Oeste.

\footnotetext{
${ }^{16}$ Segundo o IBGE (2014), no Censo Agropecuário 2006 foi adotada a codificação da Classificação Nacional de Atividades Econômicas 2.0, a qual atribuiu a atividade econômica do estabelecimento agropecuário à predominância simples da atividade que apresentou o maior valor de produção, independente da variabilidade. Assim, relacionados todos os valores de produção de todas as atividades executadas no estabelecimento agropecuário, a respectiva classe de atividade econômica foi aquela referida ao produto que obteve o maior valor de produção.
} 
Tabela 5 - Participação relativa no total de estabelecimentos rurais familiares "Pronafianos", considerando os grupos de estabelecimentos e os grupos de atividade econômica. Paraná - Microrregião de Toledo e Território Norte Pioneiro, 2006 (em \%)

\begin{tabular}{|c|c|c|c|c|c|c|c|}
\hline & Pronaf A & Pronaf B & Pronaf C & Pronaf D & Pronaf E & Total \\
\hline \multirow{3}{*}{ 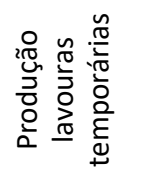 } & Paraná & 44,8 & 31,7 & 49,9 & 70,1 & 76,3 & 46,5 \\
\hline & Microrregião de Toledo & 43,8 & 36,8 & 59,9 & 70,2 & 74,2 & 59,0 \\
\hline & Território Norte Pioneiro & 25,9 & 20,4 & 20,2 & 30,8 & 43,4 & 22,8 \\
\hline \multirow{3}{*}{$\begin{array}{l}\frac{0}{0} \\
\frac{0}{3} \\
\frac{0}{3}\end{array}$} & Paraná & 7,1 & 1,9 & 17,7 & 31,3 & 42,1 & 13,5 \\
\hline & Microrregião de Toledo & 9,3 & 6,9 & 35,5 & 42,1 & 46,7 & 31,8 \\
\hline & Território Norte Pioneiro & 1,1 & 0,7 & 4,9 & 12,2 & 14,7 & 3,4 \\
\hline \multirow{3}{*}{ 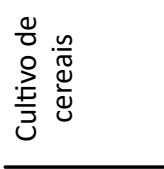 } & Paraná & 19,1 & 14,5 & 12,1 & 11,4 & 15,6 & 13,8 \\
\hline & Microrregião de Toledo & 8,3 & 9,1 & 13,5 & 19,5 & 23,2 & 15,1 \\
\hline & Território Norte Pioneiro & 14,1 & 10,0 & 7,9 & 9,3 & 20,4 & 10,3 \\
\hline \multirow{3}{*}{ 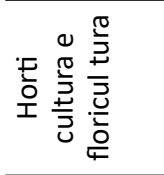 } & Paraná & 4,8 & 7,6 & 2,4 & 1,7 & 1,5 & 4,6 \\
\hline & Microrregião de Toledo & 6,7 & 6,1 & 0,7 & 0,3 & 0,3 & 1,9 \\
\hline & Território Norte Pioneiro & 3,9 & 4,2 & 2,8 & 2,3 & 3,7 & 3,6 \\
\hline \multirow{3}{*}{ 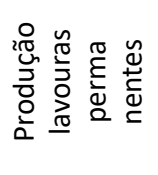 } & Paraná & 6,0 & 5,4 & 7,0 & 6,6 & 4,8 & 6,1 \\
\hline & Microrregião de Toledo & 3,8 & 3,3 & 2,3 & 2,4 & 1,6 & 2,5 \\
\hline & Território Norte Pioneiro & 26,8 & 13,4 & 34,0 & 42,1 & 39,4 & 24,9 \\
\hline \multirow{3}{*}{$\begin{array}{l}\frac{0}{0} \\
0 \\
\frac{1}{3} \\
\end{array}$} & Paraná & 3,5 & 1,8 & 5,1 & 5,0 & 4,4 & 3,6 \\
\hline & Microrregião de Toledo & 2,2 & 1,7 & 2,2 & 2,3 & 1,5 & 2,0 \\
\hline & Território Norte Pioneiro & 20,6 & 9,1 & 32,5 & 39,6 & 39,1 & 21,3 \\
\hline \multirow{3}{*}{ 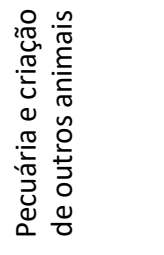 } & Paraná & 41,4 & 51,8 & 39,1 & 20,6 & 15,6 & 40,5 \\
\hline & Microrregião de Toledo & 45,0 & 52,0 & 36,4 & 26,5 & 23,0 & 35,7 \\
\hline & Território Norte Pioneiro & 42,8 & 60,9 & 42,5 & 23,7 & 13,2 & 47,8 \\
\hline \multirow{3}{*}{ 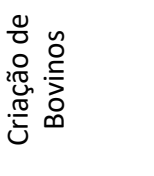 } & Paraná & 31,8 & 35,1 & 33,7 & 15,0 & 9,4 & 30,1 \\
\hline & Microrregião de Toledo & 30,9 & 38,0 & 31,4 & 16,8 & 9,5 & 26,3 \\
\hline & Território Norte Pioneiro & 33,4 & 44,1 & 37,2 & 19,5 & 8,9 & 37,1 \\
\hline \multirow{3}{*}{ 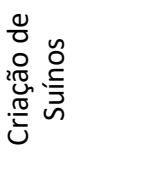 } & Paraná & 2,7 & 4,2 & 1,2 & 2,1 & 2,8 & 2,7 \\
\hline & Microrregião de Toledo & 5,3 & 4,0 & 2,4 & 6,5 & 8,3 & 4,6 \\
\hline & Território Norte Pioneiro & 2,1 & 3,4 & 0,8 & 0,9 & 0,6 & 2,2 \\
\hline \multirow{3}{*}{ 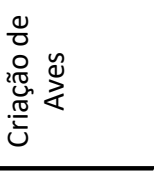 } & Paraná & 5,6 & 10,9 & 1,9 & 2,4 & 3,1 & 5,9 \\
\hline & Microrregião de Toledo & 7,3 & 7,6 & 1,8 & 3,0 & 5,0 & 3,9 \\
\hline & Território Norte Pioneiro & 5,9 & 12,0 & 1,4 & 1,4 & 2,6 & 6,7 \\
\hline \multirow{3}{*}{ 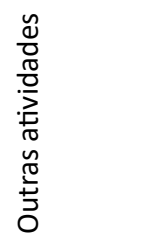 } & Paraná & 3,0 & 3,4 & 1,5 & 1,1 & 1,7 & 2,4 \\
\hline & Microrregião de Toledo & 0,8 & 1,8 & 0,7 & 0,5 & 0,9 & 0,9 \\
\hline & Território Norte Pioneiro & 0,6 & 1,2 & 0,6 & 1,1 & 0,3 & 0,9 \\
\hline
\end{tabular}


Por sua vez, no Território Norte Pioneiro, além da produção de leite, a qual se destaca sobretudo nos "pronafianos B", observa-se a importância do cultivo do café, que surge como primeira atividade em mais de $30 \%$ dos estabelecimentos "pronafianos C, $D$ e $E$ ", sendo a atividade principal do grupo $D$. Junto ao grupo $E$, o café é superado pela produção de lavouras temporárias, destacando-se, nesse grupo, o cultivo de cereais.

Por fim, a análise da ocorrência de atividades econômicas fora do estabelecimento por parte do responsável pelo mesmo ou por algum outro membro da família, mostra que, de modo geral, tais atividades estão associadas às menores condições de renda, sendo mais marcantes nos grupos B e A no Território Norte Pioneiro, quando comparado ao verificado na Microrregião de Toledo, a qual possui índices inferiores também aos constatados no Estado do Paraná (Tabela 6).

No Território Norte Pioneiro, em cerca de um terço dos estabelecimentos "pronafianos" dos grupos B e A, o responsável possuía atividades econômicas externas, sendo a menor participação, entre os grupos, de cerca de um quarto, observada junto ao grupo C.

Entre as atividades desenvolvidas externamente pelos responsáveis pelo estabelecimento, predominam, junto a todos os grupos, as atividades agropecuárias, exceto junto ao grupo $B$, no qual a presença de atividades não agropecuárias é mais frequente. Tal constatação é condizente com os resultados destacados por Schneider et al. (2014), que, ao analisarem a composição dos rendimentos dos estabelecimentos pluriativos da agricultura familiar da Região Sul do país, indicaram que 69\% desses caracterizam-se como receitas agropecuárias obtidas fora do estabelecimento.

No Território, os estabelecimentos do grupo B são também aqueles nos quais ocorre a maior proporção de atividades externas por parte de outros membros da família.

Já na Microrregião de Toledo, as atividades externas dos responsáveis pelos estabelecimentos são mais marcantes junto aos grupos $A$ e $B$, com o predomínio de atividades externas não agropecuárias, e alcança proporções muito próximas dos $20 \%$ nos três demais grupos, com predomínio de atividades externas agropecuárias. Quando consideradas as atividades externas de outros membros da família, os estabelecimentos do grupo A são aqueles mais representativos, ficando a ocorrência dessas sempre abaixo dos $19 \%$ nos quatro outros grupos. 
Tabela 6 - Participação relativa do número de estabelecimentos rurais familiares "Pronafianos", considerando os grupos de estabelecimentos e a ocorrência de atividade econômica fora do estabelecimento por parte do responsável pela direção ou algum outro membro da família. Paraná - Microrregião de Toledo e Território Norte Pioneiro, 2006 (em \%)

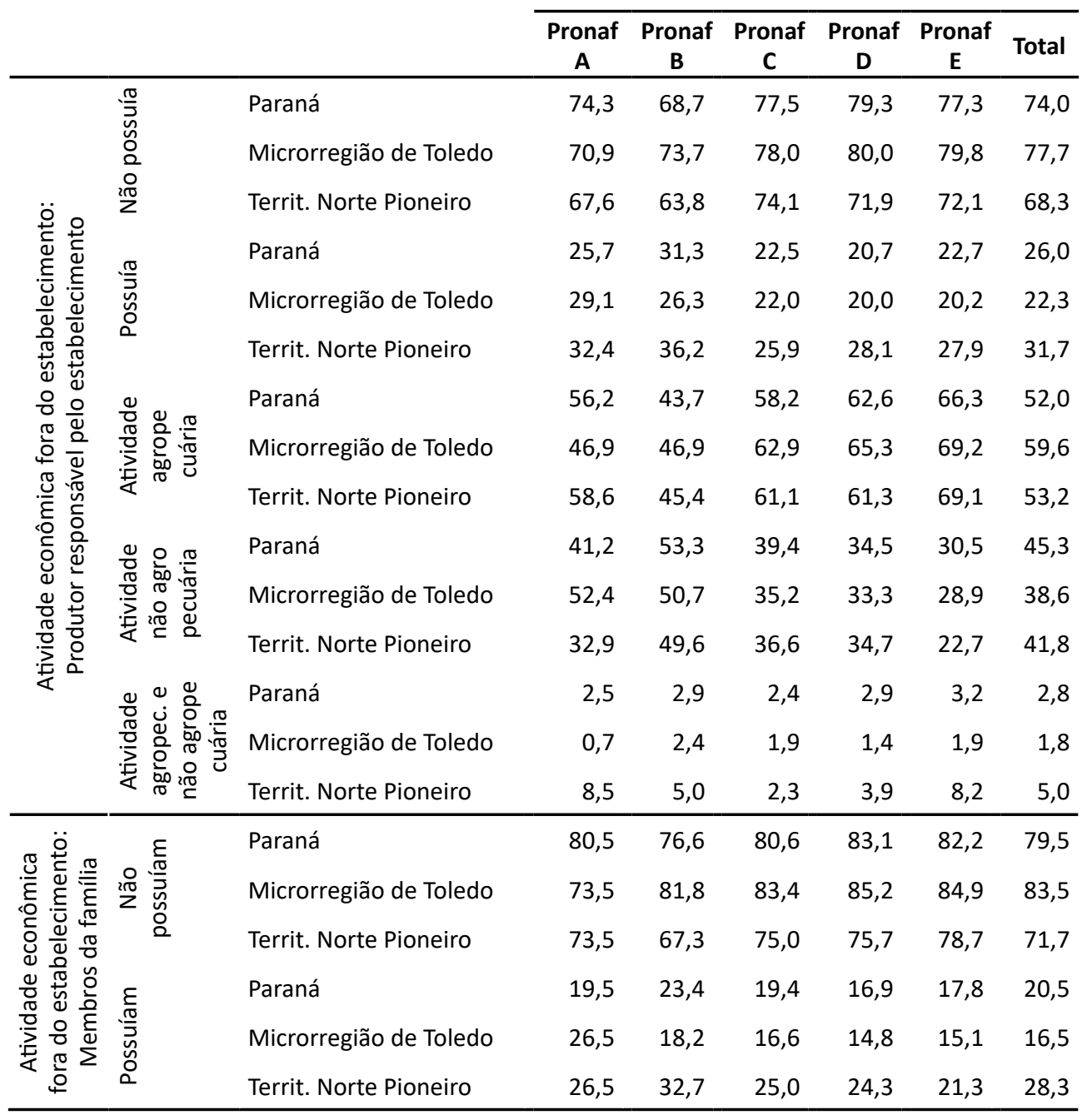

Fonte: Elaborado pelos autores a partir de IBGE, 2014.

\section{CONSIDERAÇÕES FINAIS}

A análise de algumas das variáveis disponíveis da estratificação dos agricultores familiares, realizada a partir dos critérios de enquadramento no Pronaf, permitiu identificar diferenças existentes internamente entre grupos e também entre as duas regiões estudadas.

No Território Norte Pioneiro, a participação dos "pronafianos A" ressalta a influência que ali tiveram as políticas públicas de acesso a terra, notadamente o crédito fundiário, na atual conformação do espaço agrário territorial. No mais, os baixos índices de associativismo e de disponibilidade de assistência técnica, que se generalizam entre os diferentes grupos, somado ao largo predomínio dos "pronafianos B", cuja idade média dos responsáveis pelos estabelecimentos supera os 55 anos em quase metade das uni- 
dades produtivas, ilustram as dificuldades a serem superadas, em uma situação na qual a cafeicultura ainda carrega um papel importante na agricultura regional, agora escudada pela produção de leite e de grãos.

A Microrregião de Toledo, por sua vez, com 39\% dos estabelecimentos nos grupos $D$ e E, apresenta, para esses grupos e também para os "pronafianos C" que ali predominam, taxas desejáveis de associativismo e disponibilidade de orientação técnica, ainda que voltada, em primeiro plano, aos aspectos comerciais. Também possui, todavia, desafios para os seus espaços rurais, uma vez que cerca de $46 \%$ de suas unidades produtivas, notadamente nos grupos B e A, possui áreas inferiores a 10 ha, em um ambiente que teve como vetores de desenvolvimento o cultivo de grãos e a produção de suínos e aves, atividades a cada dia mais restritivas para a capacidade de investimento de unidades produtivas desse porte.

A heterogeneidade constatada na agricultura familiar "pronafiana" no Estado e nas regiões de estudo, deve motivar análises futuras que considerem a evolução e os impactos da aplicação dessa política pública ante a diversidade observada nos tipos de unidades produtivas e na pauta de produtos, aspectos considerados em trabalhos como os de Tonneau, De Aquino e Teixeira, (2005) e Grisa, Wesz Junior e Buchweitz (2014).

\section{AGRADECIMENTOS}

Os autores agradecem à Coordenação de Aperfeiçoamento de Pessoal de Nível Superior (Capes), pela bolsa de Doutorado-Sanduíche no exterior concedida ao primeiro autor.

\section{REFERÊNCIAS}

AQUINO, J. R. et al. Dimensão e características do público potencial do Grupo B do Pronaf na Região Nordeste e no Estado de Minas Gerais. In: SCHNEIDER, S.; FERREIRA, B.; ALVES, F. (org.). Aspectos multidimensionais da agricultura brasileira: diferentes visões do Censo Agropecuário 2006. Brasília: Ipea, 2014. p. 77-106. 387p.

BARBOSA, M. Z.; NOGUEIRA JÚNIOR. (As) Simetrias entre as agroindústrias da soja no Brasil e na Argentina. Revista de Economia Agrícola, São Paulo, v. 54, n. 1, p. 87-107, jan./jun. 2007.

BRASIL, Lei № 11.326, de 24 de julho de 2006. Dispõe sobre as diretrizes para a formulação da Política Nacional da Agricultura Familiar e Empreendimentos Familiares Rurais. Disponível em:

http://www.planalto.gov.br/ccivil_03/_ato2004-2006/2006/lei/I11326.htm. Acesso em: 17 out. 2013.

CHANG, M. Y.; SEREIA, V. J. Tipificação e caracterização dos produtores rurais do Estado do Paraná, 1980. Londrina: lapar, 1993. 169p. (Boletim Técnico, n. 39).

DORETTO, M.; LAURENTI, A. C.; DEL GROSSI, M. E. Tipos de estabelecimentos agropecuários do Estado do Paraná 1995-96. Londrina: lapar, 2001. CD-ROM.

GRAZIANO DA SILVA, J. Os desafios das agriculturas brasileiras. In: GASQUES, J. G.; VIEIRA FILHO, J. E. R.; NAVARRO, Z. (Org.). A agricultura brasileira: desempenho, desafios e perspectivas. Brasília: Ipea, 2010. p. 157-184.

GRIGOLO, S. C. et al. Transformações recentes da assistência técnica e extensão rural no sul do Brasil desafios à PNATER. In: CONGRESSO DE CIÊNCIA E TECNOLOGIA DA UTFPR, 2011. Campus Dois Vizinhos, 2011. p. 123-127.

GRISA, C.; WESZ JUNIOR, V. J.; BUCHWEITZ, V. D. Revisitando o Pronaf: velhos questionamentos, novas interpretações. Revista de Economia e Sociologia Rural, v. 52, n. 2, p. 323-346, 2014. DOI: http://dx.doi. org/10.1590/S0103-20032014000200007

GUANZIROLI, C. E.; BUAINAIN, A. M.; DI SABBATO, A. Dez anos de evolução da agricultura familiar no Brasil: (1996 e 2006). Revista de Economia e Sociologia Rural, Piracicaba, v. 50, n. 2, p. 351-370, abr./jun. 2012. DOI:

http://dx.doi.org/10.1590/S0103-20032012000200009 
IBGE. Instituto Brasileiro de Geografia e Estatística. Censo Agropecuário 2006 - Agricultura familiar MDA/PRONAF (Lei no 11.326 de 24/07/2006). Disponível em:

http://www.sidra.ibge.gov.br/bda/pesquisas/ca/defaultMDA.asp?z=p\&o=2\&i=P. Acesso em: 21 nov. 2014.

INCRA. Instituto Nacional de Colonização e Reforma Agrária. Painel dos assentamentos. Disponível em: http://painel.incra.gov.br/sistemas/index.php. Acesso em: 27 nov. 2014.

IAP. Instituto Ambiental do Paraná. Módulos Fiscais dos municípios do Estado do Paraná. Disponível em: http://www.iap.pr.gov.br/modules/conteudo/conteudo.php?conteudo=1328. Acesso em: 26 nov. 2014.

IPARDES. Instituto Paranaense de Desenvolvimento Econômico e Social. Avaliação final de impacto socioeconômico da atividade Vilas Rurais. Curitiba: Ipardes, 2006. 78 p.

IPARDES. Instituto Paranaense de Desenvolvimento Econômico e Social. Diagnóstico socioeconômico do Território Norte Pioneiro: 1a fase: caracterização global. Curitiba: Ipardes, 2007. 154p.

KAgEYAMA, A. A.; BERGAMASCO, S. M. P. P.; OLIVEIRA, J. T. A. D. Uma tipologia dos estabelecimentos agropecuários do Brasil a partir do Censo de 2006. Revista de Economia e Sociologia Rural, Piracicaba, v. 51, n. 1, p. 105-122, jan./mar. 2013. DOI:

http://dx.doi.org/10.1590/S0103-20032013000100006

LAURENTI, A. C.; DORETTO, M.; DEL GROSSI, M. E. Ocupação e renda nas famílias das áreas rurais na região lindeira do lago de Itaipu. In: CONGRESSO BRASILEIRO DE ECONOMIA, ADMINISTRAÇÃO E SOCIOLOGIA RURAL, 41., 2003, Juiz de Fora. Anais [...]. Juiz de Fora: Sociedade Brasileira de Economia, Administração e Sociologia Rural, 2003.

MADUREIRA, E. M. P. Análise das principais cadeias de produção agropecuárias no processo de crescimento econômico do Oeste do Paraná: 1985-2010. 2012. 118f. Dissertação (Mestrado em Desenvolvimento Regional e Agronegócios) - Universidade Estadual do Oeste do Paraná, Toledo, 2012.

RIPPEL, R. Migração e desenvolvimento econômico no Oeste do Estado do Paraná: uma análise de 1950 a 2000. 2005. 250f. Tese (Doutorado em Demografia) - Instituto de Filosofia e Ciências Humanas, Universidade Estadual de Campinas, Campinas, 2005.

SACCO DOS ANJOS, F.; CALDAS, N. V.; POLLNOW, G. E. Menos mulheres, menos jovens, mais incertezas. A transição demográfica no Brasil Rural Meridional. Extensão Rural, Santa Maria, v. 21, n. 2, p. 94-116, abr./ jun. 2014. DOI: http://dx.doi.org/10.5902/2318179610453

SANTOS, F. F. Políticas fundiárias e desenvolvimento local: o papel do Banco da Terra na reconstrução do rural. 2005. Tese (Doutorado em Sociologia) - Departamento de Ciências Sociais, Universidade Federal do Paraná, Curitiba. 2005.

SANTOS, G. R.; VIEIRA FILHO, J. E. R. Heterogeneidade produtiva na agricultura brasileira: elementos estruturais e dinâmicos da trajetória produtiva recente. Brasília: Ipea, 2012. 32p. (Texto para Discussão, n. 1.740).

SCHNEIDER, S. et al. Pluriatividade e plurirrendimentos nos estabelecimentos agropecuários do Brasil e das Regiões Sul e Nordeste. In: SCHNEIDER, S.; FERREIRA, B.; ALVES, F. (org.). Aspectos multidimensionais da agricultura brasileira: diferentes visões do Censo Agropecuário 2006. Brasília: IPEA, 2014. p. 107-133. $387 p$.

SCHNEIDER, S.; CASSOL, A. Diversidade e heterogeneidade da agricultura familiar no Brasil e algumas implicações para políticas públicas. In: DELGADO, G. C.; BERGAMASCO, S. M. P. P. (org.). Agricultura familiar brasileira: desafios e perspectivas de futuro. Brasília: Secretaria Especial de Agricultura Familiar e Desenvolvimento Agrário, 2017. p. 82-107.

SILVA, R. P. As especificidades da nova Ater para agricultura familiar. Revista Nera, n. 23, p. 150-166, 2014. SILVA, L. H. A.; CAMARA, M. R. G.; TELLES, T. S. Evolução e distribuição espacial da produção de leite no Estado do Paraná, Brasil. Acta Scientiarum. Human And Social Sciences, Maringá: v. 38, n. 1, p. 37-47, 24 jun. 2016. DOI: http://dx.doi.org/10.4025/actascihumansoc.v38i1.30006.

SOARES JÚNIOR, D. et al. Recent changes in agrarian systems of the Microregion of Toledo and Northern Pioneer Territory in Paraná State, Brazil. Semina. Ciências Agrárias (on-line), v. 38, p. 699-714, 2017. DOI: http://dx.doi.org/10.5433/1679-0359.2017v38n2p699

SOUZA, M.; DEL GROSSI, M. E. As Vilas Rurais no Estado do Paraná: uma política não-agrícola com viés agrícola. Reforma Agrária, Campinas, v. 30, n.3, p. 61-84, 2000.

SOUZA FILHO, H. M. et al. Condicionantes da adoção de inovações tecnológicas na agricultura. Cadernos de Ciência \& Tecnologia, v. 28, n. 1, p. 223-255, 2011. Disponível em: http://seer.sct.embrapa.br/index. php/cct/article/view/12041. Acesso em: 21 ago. 2014.

TONNEAU, J-P.; DE AQUINO, J. R.; TEIXEIRA, O. A. Modernização da agricultura familiar e exclusão social: o dilema das políticas agrícolas. Cadernos de Ciência \& Tecnologia, v. 22, n. 1, p. 67-82, 2005. 